\title{
EMPIRICAL STUDY ON THE DETERMINANTS OF THE QUALITY OF WORKLIFE IN LOCAL GOVERNMENT INSTITUTIONS
}

\author{
Kamila Kuczaj \\ Jagiellonian University in Kraków \\ e-mail: kuczaj.kamila@gmail.com \\ DOI: $10.15611 /$ noz.2017.4.06 \\ JEL Classification: D01, D22, H89
}

\begin{abstract}
Summary: The relationship between quality of worklife (QWL) and particular work aspects has been heavily re-searched over the years. Despite this continuous interest, there is no commonly recognized list of determinants of QWL that has been accepted by the majority of researchers. This study tests ten major job factors, and their relationship with worklife quality is presented and discussed. The results are based on quantitative data that was collected via questionnaire. This type of analysis has not previously been conducted in Poland in the public sector. The results, based on a regional probability sample of office workers, help to define the determinants of quality of worklife in local government institutions. The results indicate a relatively strong relationship between four of the ten described job aspects and QWL. The paper contains a list of conditions that are conducive to the development of QWL in local government, as well as institutional recommendations.
\end{abstract}

Keywords: quality of worklife (QWL), QWL determinants, public sector, local government.

\section{Introduction}

The purpose of this paper is to present the results of an empirical study on the quality of worklife (QWL) in three local government institutions. The article distinguishes the job factors that have the most significant relationship to QWL. These factors are presented as determinants of quality of worklife.

The concept of QWL is not a trivial marketing product, or a duplicate idea under a changed name from the human resources area. Rather, it is a groundbreaking way of thinking, a philosophy, and a trend toward a change in mentality that has, for years, divided workers into supervisors and subordinates. This mentality is used to eliminate direct dialogue and promote trade unions as a forum of communication, particularly for dispute resolution. QWL gave rise to the humane treatment of workers, and led to the acceptance of basic humanitarian principles that addressed the needs and expectations of an employee. Ultimately, QWL sparked an interest in respect for the individual's dignity, morale and values in the workplace.

Beginning in the 1970's, various definitions of QWL have emerged in the literature [Beh, Raduan
2007, p. 30]. Principally, these definitions of QWL include: a repair program, overall quality of experience at a workplace, and a process or philosophy. As a repair program, QWL is a human resources management tool that focuses on the needs of employees to reach the organization's goals. As a process, QWL embraces actions that aim to improve the function of employees in the organization and, at the same time, to boost the organization's performance. As a philosophy, QWL is a way of thinking and an approach to the employee that has been shaped over decades, and today is a part of organizational culture. As a set of experiences, QWL reflects the employee's perception of the quality of experiences in various spheres of work.

The QWL movement picked up in the 1980s when competition between Japan and the United States caused US producers to have difficulty with increasing their production to match the price and quality and Japanese imports [Guzda 1984, p. 26]. Over the years the U.S.A labor market has evolved, and with it came the employee value system and its needs at work. In the 1970s and 80s in the United States, there was a strong pro-quality movement that fought dehuma- 
nization in the workplace. The US national economic report of 1978 [http://www.presidency.ucsb.edu/ econo-mic_reports/1978.pdf, pp. 15-16] found that the economic downturn was mainly caused by a decline in productivity levels. In the early 1970s, the U.S. began paying attention to work dissatisfaction in both blue- and white-collar workers. This trend lasted until the 1980's, at which time the declining level of job satisfaction and the general mood is depicted in the publication, "Where have all the robots gone?" which discusses the omnipresent alienation, anxiety and frustration of the US workforce [Turner 1973, p. 11]. This situation was the second major cause of the pro-quality movement. An example of this was the decline in enthusiasm among General Motors employees in the early 1970s when the manufacturing plant became largely automated. This frustration was manifested via an increase in employee protests. In a report by the US Department of Health, Education and Welfare in America in 1973, Senator Edward Kennedy raised the issue of worker alienation, which shocked the public due to evidence of psychological and physical violence in the workplace [Granter 2016, pp. 188-190]. The third factor that advanced the QWL movement in the US were the different work ethics represented by the new generation of "Baby Boomers." During this period of prosperity and upheaval, the "Baby Boomers" represented about $40 \%$ of the workforce, culminating in a change in the workplace profile and the expectations associated with it. Traditional, rural society began to transform into a modernized and urbanized group of people, among whom the patriarchal and ruling tendencies started to dissolve [Lowe 2001, p. 33]. These changes also caused a transformation in the approach to human capital in organizations. A decade later, businesses were already beginning to recognize the principle that high quality personnel would allow maintenance of their competitive advantage, rather than capital, technology, or durable goods [Caudron 1994, pp. 3036]. In today's commercial world, a productive workforce increases productivity and efficiency, and is essential for gaining and maintaining sustainable competitive advantages for business organizations on a global scale [Chan, Wyatt 2007, p. 503] QWL aims to improve the quality of employee experiences in the workplace so as to boost organizational and individual performance. From an organizational perspective, QWL is important, since there is evidence that the nature of the work environment is related to the satisfaction of its employees and their work-related behaviors [Greenhaus et al. 1987, p. 209]. QWL is also found to effect employees' work attitudes, which are reflected in organizational identification, job satisfaction, job involvement, effort and performance, intention to quit, organizational turnover, and personal alienation [Chan, Wyatt 2007, p. 502]. In a review of the literature on work health and well-being, there is a link between those who experience greater QWL and higher levels of health and well-being [Danna, Griffin 1999, pp. 357-384]. Conversely, other work-related behaviors such as absenteeism, reduced productivity and efficiency appear to be affected by a low level of QWL [Marks et al. 1986, pp. 61-69].

\section{Definition and basic concepts presented in the paper}

This paper refers to three basic concepts: quality of worklife, determinants of QWL, and local government institutions.

These days, QWL is a term used in almost every area of organizational activity [Beh, Raduan 2007, p. 30]. Yet, its definitions tend to change focus, so it has been perceived in different ways: as organizational interventions (also called repair programs), and as quality of experiences in the workplace (reflecting the affective evaluation of individuals) [Wyatt, Wah 2001, p. 61]. QWL can also be viewed as a philosophy that represents strong humanistic principles. As a process, QWL involves democratic values and procedures. As a set of results, it refers to the perceived outcomes resulting from improved organizational effectiveness and increased job satisfaction [Carlson 1983, p. 45]. As used in this paper, QWL is a process that aims to improve working conditions to achieve the highest possible level of employee' satisfaction. Therefore, QWL is viewed as the quality of individuals' experience in the workplace.

QWL is measured by evaluating determinants of an employee's work. Several models of quality of life in the workplace are described in the literature, but the most widely used by the researchers is the "EightFactor QWL Model" by Richard Walton [Walton 1974, p. 12]. This model identifies the following eight determinants of QWL: adequate and fair remuneration, safe and secure workplace, opportunity to use and develop skills, career prospects, social inclusion, constitutionalism in the work organization, quality of life outside work, and the special meaning of work. Based on Walton's assumptions, the author proposed a 10-factor model of QWL in local government.: pay, social climate, professional and career development, physical conditions of the workplace, equality (constitutionalism), autonomy, communication, stress, mission and vision, and work ethics. In Walton's work, ethics is a part of constitutionalism. The current paper's model does not include the meaning of work 
and quality of life. The selection of QWL determinants is elaborated later in the methodology section of the paper.

The third topic covered in this paper is local government. In Poland, the structure of government has two branches: central (state) government administration (similar to the federal government in the U.S.), and local government. Local governments are split into three groups based on the size of the governed area: 'voivodships' (also translated as provinces, or states in the U.S. system), 'powiats' (also translated as districts, or counties in the U.S. system), and 'communes' (also translated as munici-palities, or city/village councils in the U.S. system). These all provide services to the local community, but only the first two (provinces and districts) share responsibility with the central government. The major characteristic of local governments is that they are self-governing bodies. The district (the research object of this paper) performs public tasks that exceed the municipalities' responsibility and include: technical infrastructure (transportation), social infrastructure (public education, health care, family policy, culture, tourism, unemployment, consumer rights, promotion of the county). The district also secures public order and security (natural disasters, defence), and civil and ecological order (civil engineering and construction, water management, agriculture, forestry and inland fisheries, environmental protection). The district/ county also performs statutory tasks on its own behalf and on its own responsibility [http://www.regioset.pl/ monitor.php?lg=0\&art=6\&unit=4].

\section{Methodology and research instruments}

The research reported in this article is a part of the author's doctoral study, which was conducted in four stages. As an introduction to the empirical research, the author thoroughly reviewed the literature on the subject; extended knowledge about the subject allowed the construction of the scheme of the empirical study. Its first stage was carried out in 2013, and was the initial design and pilot test of a research tool. The pilot study's purpose was to better understand the issue of QWL in the workplace of employees from the public sector. It asked respondents from the public and private sector $(n=90)$ to rank the job aspects from most to least important on a Likert scale. The scale included 11 items: adequate and fair compensation, system of rewards and punishments; fringe benefits, stability of employment, physical working conditions and safety at the workplace, working hours, low level of stress in the workplace, opportunities for continuous improvement, education and development, social aspect - relations with the employer and colleagues at work, participation in decision-making, independence, autonomy, variety of tasks, creative and challenging work, equal treatment, an counteracting violence/ abuse. It should be noted at this point that the main problem in using Walton's "Eight-Factor Model" is its lack of a detailed description of particular components, and the overly sophisticated description that makes it cumbersome to understand for both practitioners and theorists. Based on Walton's QWL model, and the results of the pilot study (which included selection of the most important job aspects), the author created a questionnaire asking about the ten most important QWL determinants. This questionnaire was distributed to employees at three offices included in the research study in 2015. The first stage of the study helped the author to determine the major influencers on QWL. The second stage served as a tool for improving the research instrument (questionnaire).

The third stage of the research (which was the main focus of the study) was conducted between January and February 2016. It involved administering the revised research instrument to a stratified sample $(n=227)$ from three local government institutions at the county level: Limanowa, Nowy Targ and Nowy Sącz. The respondents represented all organizational levels: administrative, managerial, interns, and independent contractors. To maintain confidentiality, the completed questionnaires were returned separately in sealed envelopes. The research instrument was addressed to all employees of the investigated offices, Nonprobabilistic purposive sampling was used. The QWL portion of the research instrument consisted of four questions, demographics, and open- and closed-ended questions. There were 72 items in the questionnaire on QWL. The respondents were asked to express their views on the various statements in a Likert scale ("I strongly agree", "I agree", "do not know", "disagree", "strongly disagree"). Finally, the respondents were requested to state their gender, age, marital status, education, work tenure, and work position.

To examine the relationship between the various aspects of work and QWL, the author applied a correlation analysis. The nature of the research is determined by the fact that the study of the entire population could be difficult, so in this case a test sample was selected for the study. Non-probabilistic purposive sampling was used for the sample.. The author had prior knowledge of the studied population and the objectives of the study. This knowledge resulted from personal experience via work in a marshal's (marszałek) office, as well as several years of close cooperation with a county office as part of the author's professional activity. 
The fourth stage of the empirical study was qualitative. The author conducted expert interviews with the managerial staff including county executives (starosta). This qualitative analysis sought to ask how the respondents perceived QWL, what QWL means to them, what they most like about their job, the status that their work has in their life, if they like their job, and how they imagine their future career path. They were also queried about any flaws in their workplace.

Table 1. Research stage, instrument and number of respondents

\begin{tabular}{|c|l|l|c|}
\hline & Reseach stage & \multicolumn{1}{|c|}{ Research instrument } & $\begin{array}{c}\text { Number } \\
\text { of respondents }\end{array}$ \\
\hline 1. & $\begin{array}{l}\text { I - preliminary } \\
\text { study }\end{array}$ & Poll - ranking of job aspects & 90 \\
\hline 2. & $\begin{array}{l}\text { II - preliminary } \\
\text { study }\end{array}$ & $\begin{array}{l}\text { Questionnaire on the quality } \\
\text { of worklife, job satisfaction } \\
\text { and organizational commitment }\end{array}$ & 265 \\
\hline 3. & III - main study & $\begin{array}{l}\text { Questionnaire on the quality } \\
\text { of worklife, job satisfaction } \\
\text { and organizational commitment }\end{array}$ & 227 \\
\hline 4. & IV - main study & In-depth expert interview & 35 \\
\hline
\end{tabular}

Source: own work

Table 1 lists the stages, research tools and number of participants of each stage of the study.

\section{Researched population}

The public sector in Poland provides employment for $23 \%$ of all working Poles, or about one million people (of which 444 thousand work in public administration and 260 thousand are employed in local "selfgovernment") [http://wiadomosci.wp.pl/kat,140714, title, W-Polsce-wzrasta-liczba-urzednikow-Jest-ichjuz-ponad-444-tysiace,wid,17527914,wiadomosc. $\mathrm{html}$ ?ticaid=1177e6\&_ticrsn=3]. There are 314 'powiats' (districts/counties) in Poland and 66 cities with a 'powiat' status. The survey was conducted between January and February 2016. The respondents were employees of three districts: Limanowa, Nowy Targ and Nowy Sacz; 227 office staff employed in three local government offices participated in the research. In total, 360 questionnaires were distributed (the number was made up of the office workers delegated by the heads of the offices). There was a $63 \%$ response rate $(\mathrm{N}=227.70 \%$ of the respondents were female and $30 \%$ male). The majority (68\%) were young and middle-aged (26-45-years-old) Only $8 \%$ of younger people (under 25) participated in the study. The majority $(87 \%)$ of the respondents had completed higher education. There were no people with education lower than secondary school. Most of the studied population lived with their family $(83 \%)$; and $63 \%$ of the respondents had over ten years of tenure $(7 \%$ had less than two years of tenure). Most employees were administrative staff $(74 \%)$ and $9 \%$ were in managerial positions.

Based on the author's knowledge and experience, it was presumed that public administration employees are a specific research sample. The organizational climate that prevails at county offices is different from the climate in private companies, and motivational factors are also different. Therefore, the QWL research tool is adapted specifically for the needs of such a research object. The three selected offices are demographically and structurally similar. They are located in the Małopolskie voidship and are distant from a large urban center by about $65-75 \mathrm{~km}$. They are located in towns not exceeding 50,000 residents. The ratio of employment structure (urban vs. rural) is similar in all three places. In the following part of the paper, the study results for all three offices are presented in a cumulative average value (not separately for each).

\section{Research results}

Based on the conducted research it was found that there is a positive correlation $(0.35)$ between the quality of worklife and compensation (covering basic needs, feeling of justice in the matter of remuneration). Also, a correlation 0.30 was proved between QWL and the physical conditions of the workplace (chair, desk, lighting). A positive correlation (0.38) was found between QWL and communication at work (flow and access to current information in the office). Similarly, a positive correlation (0.38) was proved between the quality of worklife and the organization's mission and vision (the knowledge of and the sense of their pursuit) (0.38). A negative correlation $(-0.37)$ was found between the quality of life in the workplace and stress (stress generated at work).

The conducted studies confirmed a positive correlation (0.50) between the quality of life in the workplace and the social climate (good relations with the supervisor and colleagues). There was a positive correlation (0.58) between QWL and development (professional, improvement of skills, acquiring new knowledge). and correlation (0.47) between QWL and decision-making (the ability to make own decisions related to work, e.g. how to solve a given problem at work). And finally, there were positive correlations ( 0.41 and 0.54 , respectively) between quality of life in the workplace and fair treatment (mainly by the supervisor), and between QWL and work ethics 0.54.

Restating the above, the significant determinants of QWL in the surveyed offices are: professional development, workplace ethics, social climate and decision-making. 


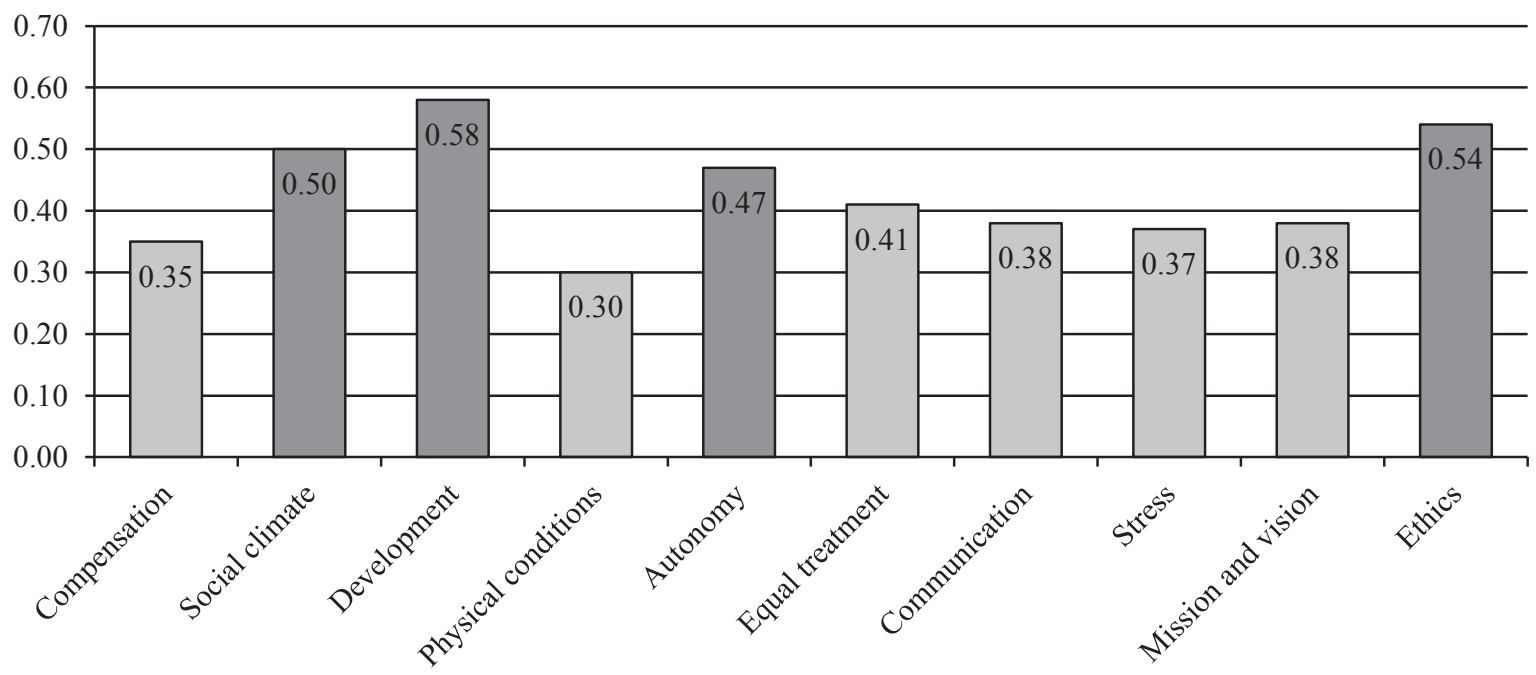

Fig. 1. Relationships between QWL and particular job aspects.

Source: own research.

Figure 1 presents a summary of the above results (insignificant indicators are illustrated in a light shade of gray, i.e. with a correlation lower than 0.3 ; significant factors, i.e. with a correlation above or equal 0.47 are shown in the dark shade of gray).

Based on the presented results, the final part of the paper provides the discussion and the author's main conclusions as well as the future direction of the research.

\section{Discussion, conclusions and recommendations}

It is important to note that this research had certain limitations. First of all, this was an exploration of opinions and not a study of a factual state. Secondly, there is lack of prior research studies in Poland on the topic. Previously conducted studies covered single areas of QWL, for instance: interpersonal relations, work burnout, career prospects and professional development, and job satisfaction. The unquestionable advantage of QWL is that it investigates all organizational areas at a time. This allows the researcher to obtain a more objective and full organizational picture at a given point in time. In addition, more correlations can be found among particular dimensions or singular items on a QWL scale, making the tool more useful for organizations. Strained and residual information (studies conducted separately) analyzed jointly would not provide as ample and objective research outcomes. Therefore, this is a benefit of a QWL study, but also a shortcoming, as the whole process is more extensive and difficult for the researcher, especially at the phases of devising a research instrument and analyzing the results.

From the research conducted in the group of 227 employees of three local government offices in Poland, the author defined a list of determinants and conditions conducive to their improvement. Table 2 lists both.

Table 2. Determinants of QWL and conditions conducive to their improvement

\begin{tabular}{|l|l|l|}
\hline QWL determinant & \multicolumn{1}{|c|}{ Type } & \multicolumn{1}{c|}{ Conducive conditions } \\
\hline $\begin{array}{l}\text { Professional } \\
\text { development }\end{array}$ & Organizational & $\begin{array}{l}\text { Opportunity to participate in training, postgraduate studies, training connected with work } \\
\text { tasks }\end{array}$ \\
\hline Ethics & $\begin{array}{l}\text { Organizational and } \\
\text { socio-psychological }\end{array}$ & Following the rules and regulations of an organization. Improving trust \\
\hline Social climate & Socio-psychological & Good interpersonal relations, knowledge sharing and good cooperation with the supervisor \\
\hline Decisiveness & Organizational & $\begin{array}{l}\text { Freedom of co-decisiveness regarding work or functioning of a department, empowerment, } \\
\text { using involvement Practices }\end{array}$ \\
\hline Mission and vision & Organizational & Identification with mission and vision of an organization, knowing the mission and vision \\
\hline Fairness & Socio-psychological & $\begin{array}{l}\text { Feeling of being treated fairly and equallywith others regardless of age, gender, age or work } \\
\text { tenure }\end{array}$ \\
\hline Leadership style & Socio-psychological & $\begin{array}{l}\text { Preferred autocratic style: listens to opinions of clerks, consults decisions, has leader } \\
\text { features and can manage groups of people }\end{array}$ \\
\hline
\end{tabular}

Source: own research. 
Based on the results of this study, the following recommendations for the government institutions targeted in this study are proposed:

1. Use customer satisfaction surveys to improve the work of the office.

2. Introduce personnel audits in the hiring process to better allocate human resources.

3. Introduce flexible forms of employment.

4. Create more opportunities for professional development (compulsory training, management training, and communication skills training).

5. Introduce an Employee Satisfaction Survey (with QWL elements).

6. Introduce or make a better use of the existent employee evaluation and check the compliance with evaluation recommendations.

7. Introduce the obligation that employees become acquainted with the mission and vision of the organization, and familiarize themselves with how the mission translates into the everyday tasks and actions.

8. Use participatory methods and encourage communication of ideas to improve the functioning of individual departments.

9. Promote and monitor equal treatment (for instance through employee surveys).

In the presented research, local government offices were selected to participate due to the researcher's scientific interest in these institutions. Observation of the public sector in Poland over the years has demonstrated the changes taking place in counties/ 'powiats' are moving in the right direction. On the other hand, these changes could be better targeted to further improve the functioning of local government offices. Improvement in the QWL would improve the perceived quality of the worklife of internal customers (employees) and, what often comes with it, the quality of service perceived by external customers (constituents). This study helped to establish the determinants of quality of worklife in local government but further research on this subject will be helpful help to support the use of QWL moving forward. For this purpose, the relationship between the level of QWL in local government offices and their level of performance should be examined further. In Poland there is a Ranking of Polish Districts [Ranking powiatów 2017] which monitors the activities of local government offices on an ongoing basis by assigning points in different categories. These categories include: proinvestment and pro-development measures, solutions improving quality of service, development of information society, development of civic society, strengthening information security management systems, promotion of healthcare solutions and social assistance, support for market economy actions, promotion of eco-energy and eco-friendly solutions, national and international cooperation, and promotional activities. According to the author, an impartial institution should supervise and evaluate the functioning of each government office. Another conclusion is that there is a possibility to develop an improved QWL model based on the CAF model (Common Assessment Framework) or its sister model EFQM. The EFQM (Excellence Model of the European Foundation for Quality Management) consists of ten areas, which similarly to QWL focuses on: leadership which includes creating and communicating visions, values, ethics and motivation; employee engagement which embraces human resources development, competence research, communication and motivation; processes, namely design and process improvement; employee satisfaction via opinion polls; partnership and resources which include information management and technical infrastructure. These areas of the EFQM can be used to develop a model for managing people in local government.

Looking closer at the problems of modern management, some companies are too hasty in giving up some of the concepts of management, and there is an inconsistency regarding terminology defining the methods, approaches, and practices of contemporary managers. There is a need for holistic solutions that would define the ways to target improvement without limiting the management methods used. Many of the applied management methods fail to deliver satisfactory results due to fear of change and organizational chaos [Bugdol 2003, pp. 145-147]. Many supervisors do not acknowledge the significance of change, do not possess sufficient knowledge of the methods being implemented, and/or do not have the appropriate communication skills that could serve as a tool of cooperation and clarification of the implemented changes. Most articles published so far present the benefits of implementing a QWL improvement program but do not analyze its weaknesses. Although the conducted research has its limitations, as mentioned earlier in the paper, the study may turn out to be beneficial to both theorists and practitioners in the area of human resource management. A comparative study on the differences in the level of QWL in particular offices would prove complementary to the present research. The results of a qualitative study would provide an in-depth knowledge on these differences. Qualitative methods would also prove useful in gaining a better insight into the degree of QWL practices in different institutions. Finally, future research will help to provide a discernable pattern applicable to a wider sample of organizations. 


\section{Bibliography}

Beh L.S., Raduan Ch.R., 2007, Linking QWL and job performance: Implications for organizations, Performance Improvement, 46.6.

Bugdol M., 2003 Zarządzanie przez jakość. Zagadnienia społeczne, Wydawnictwo Uniwersytetu Opolskiego, Opole, pp. 145 $-147$.

Carlson H.C., 1983, A model of quality of work life as a developmental process, Education+ Training, 25.1.

Caudron S., 1994, De-jobbing of America, Industry Week 243(16), pp. 30-36.

Chan K.W., Wyatt T.A., 2007, Quality of work life: a study of employees in Shanghai, China, Asia Pacific Business Review, 13(4).

Danna K., Griffin R.W., 1999, Health and well-being in the workplace: a review and synthesis of the literature, Journal of Management, 25(3), pp. 357-384.

Davis, L.E., 1983. Design of new organizations. The Quality of Working Life and the 1980s, New York: Praeger Publishers, pp. $65-86$

Granter E., 2016, Critical social theory and the end of work, Routledge.

Greenhaus J., Bedian A., Mossholder K., 1987, Work experiences, job performances, and feelings of personal and family well being, Journal of Vocational Behaviour. 31(2), pp. 200-215.

Guzda H.P., 1984, Industrial democracy: made in the USA, Monthly Lab. Rev., 107.

Herzberg F., 1987, How do you motivate employees, Harvard Business Review.

http://wiadomosci.wp.pl/kat, 140714,title,W-Polsce-wzrasta-liczba-urzednikow-Jest-ich-juz-ponad-444-tysiace, wid, 17527914, wiadomosc.html?ticaid $=1177 \mathrm{e} 6 \&$ ticrsn=3, 19 Feb 2016.

http://www.presidency.ucsb.edu/economic reports/1978.pdf, 15 Aug 2017.

http://www.regioset.pl/monitor 2014, 15 Aug 2017.

https://www.nlrb.gov/sites/default/files/attachments/basic-page/ node-1677/nlrb1978.pdf, 20 Sept.

Khtevath P., 2015, An Empirical Analysis of Quality of Work Life of Employees in Indian Private Sector Organizations, icehm. org/upload/9025ED0315032.pdf, 21 Jan 2017.
Kitratporn, P. and Puncreobutr, V., 2016. Quality of Work Life and Organizational Climate of Schools Located along the Thai-Cambodian Borders. Journal of Education and Practice, 7(11), pp.134-138.

Kohn A., 1993, Why incentive plans cannot work, Harvard Business Review, 71.5.

Koonmee, K., Singhapakdi, A., Virakul, B. and Lee, D.J., 2010, Ethics institutionalization, quality of work life, and employee job-related outcomes: A survey of human resource managers in Thailand. Journal of business research, 63(1), pp. 20-26.

Kuczaj K., 2017, Meaning of quality of worklife. Factors and barriers to development of QWL in Polish local government, Jagiellonian University, Krakow.

Lowe G.S., 2001, Quality of Work-Quality of Life, Keynote address to the "Work/Life Balance and Employee Wellness Strategies" Conference, Edmonton.

Marks M.L., Mirvis P.H., Hackett E.J., Grady J.F., 1986, Employee participation in a quality circle program: impact on quality of work life, productivity, and absenteeism, Journal of Applied Psychology, 71(1).

Moghimi, Seyed Mohammad, Masoumeh Kazemi, Saied Samiie, 2013, Studying the relationship between organizational justice and employees' quality of work life in public organizations: a case study of Qom Province, Iranian Journal of Management Studies, 6.1

Nanjundeswaraswamy, T.S. and Sandhya, M.N., 2016. Quality of Work Life Components: A Literature Review.

Pfeffer J., 1997, Six dangerous myths about pay, Harvard Business Review, 76.3.

Prasad M., 2016, An evaluation of the quality of work life: a study of public sector nurses in West Bengal, Asian Journal of Nursing Education and Research, 6.2.

Ranking powiatów powyżej 120 tys. mieszkańcow 2017, http:// ranking.zpp.pl/index.php?action $=$ ranking $\& \mathrm{ctl}=$ ranking Main\&id=3, 14.08.2017.

Turner A.N., 1973, Where have all the robots gone? Worker dissatisfaction in the 70S, Administrative Science Quarterly, 18.3, pp. 414-416.

Walton R.E., 1974, Improving quality of work life, Harvard Business Review, 52.3.

Wyatt T.A., Wah C.Y., 2001, Perceptions of QWL: A study of Singaporean employees development, Research and Practice in Human Resource Management, 9(2).

\section{DETERMINANTY JAKOŚCI ŻYCIA W MIEJSCU PRACY W JEDNOSTKACH SAMORZĄU TERYTORIALNEGO - WYNIKI BADAŃ EMPIRYCZNYCH}

Streszczenie: Związek między jakością życia w miejscu pracy (QWL) a poszczególnymi aspektami pracy badano na szeroką skalę w ostatnich latach. Pomimo ciągłego zainteresowania nie ma w środowisku badaczy wspólnego stanowiska dotyczącego listy determinant QWL. W niniejszym badaniu zweryfikowano związek między QWL a dziesięcioma głównymi aspektami pracy. Takie badania nie zostały dotyczas przeprowadzone w Polsce w sektorze publicznym. Badania zrealizowano w 2016 r. metodą ilościową - z wykorzystaniem kwestionariusza ankiety. Wyniki oparte na próbie 227 urzędników trzech starostw powiatowych w województwie małopolsim pomogły określić czynniki wpływające na jakość życia w miejscu pracy w badanych instytucjach samorządowych. Istotny związek między pięcioma z dziesięciu opisanych aspektów pracy a QWL został potwierdzony. W artykule zaprezentowane są warunki sprzyjające rozwojowi QWL w samorządzie terytorialnym oraz rekomendacje dla badanych instytucji.

Słowa kluczowe: jakość życia w miejscu pracy (QWL), determinanty jakości życia w miejscu pracy, sektor publiczny, samorząd terytorialny. 